Cuad. Invest. Filol., 43 (2017), 233-248. http://doi.org/10.18172/cif.2955

\title{
PERFORMATIVE VERBS IN REQUESTS: EVIDENCE FROM EIGHTEENTH-CENTURY LETTERS
}

\author{
Fátima Faya Cerqueiro \\ Universidad de Castilla-La Mancha \\ Fatima.Faya@uclm.es
}

\begin{abstract}
In the second half of the eighteenth century the courtesy marker pray was the default pragmatic marker used in polite requests while the new form please started to emerge. Pray was a grammaticalized form originated in the longer performative expression I pray you/thee, whereas the verb please had a different syntactic pattern. In the same period there were other performative expressions, particularly common in the epistolary genre, with the same syntactic pattern observed in (I) pray (you) and also used in directives. They resorted to the wide variety of requestive verbs available in Late Modern English, such as beg, beseech, desire, entreat, and request. This paper examines the set of different performative expressions used as polite request markers in the Corpus of Late Eighteenth-Century Prose (1761-1790) in order to provide an account of their productivity and functions in the second half of the eighteenth century.

KEYWORDS: performatives, requests, politeness, epistolary genre, eighteenth century.
\end{abstract}

\section{VERBOS PERFORMATIVOS EN PETICIONES: EVIDENCIA EN CARTAS DEL SIGLO XVIII}

RESUMEN: En la segunda mitad del siglo XVIII el marcador de cortesía pray era el marcador pragmático más habitual en peticiones mientras que la nueva forma please empezaba a surgir. Pray era una forma gramaticalizada con origen en el performativo I pray you/thee, pero please tiene un origen sintáctico diferente. En el mismo periodo se utilizaban otras expresiones performativas, frecuentes sobre todo en cartas, con el mismo patrón sintáctico que (I) pray (you) y que también se usaban en directivos. Estas expresiones hacían uso de la gran variedad de verbos de petición disponibles en el periodo de inglés moderno tardío, como beg, beseech, desire, entreat $y$ request. Este trabajo revisa el conjunto de expresiones performativas utilizadas como marcadores de cortesía en peticiones en el Corpus of Late Eighteenth-Century Prose (1761-1790) para revisar su productividad y las funciones desempeñadas en la segunda mitad del siglo XVIII.

PALABRAS CLAVE: performativos, peticiones, cortesía, género epistolar, siglo XVIII.

Recibido: 04/08/2016. Aceptado: 15/02/2017 


\section{Introduction}

Directive speech acts have become an interesting source to gather linguistic and extralinguistic information about previous stages of the language since they might reflect ongoing changes in societies and individuals (cf. Culpeper and Demmen 2011; Włodarczyk 2013). In this respect, Sönmez (2005) analyses several requestive verbs such as beg, beseech, desire, entreat, please, pray, and request in her study on this speech act in seventeenth-century family letters, and finds revealing results concerning the selection of request markers depending on variables such as age.

Some of these expressions were extremely productive and often used parenthetically as downtoners to soften the imposition of the request, as in the case of (I) beg, which reached a substantial level of conventionalization. The fact that there were so many expressions used with similar functions may be related to sociolinguistic factors due to the important role played by politeness in the eighteenth century (Klein 2002). In fact, the characteristic eighteenth-century abundance of mitigating devices in the speech act of requests and the frequent use of both conventional and non-conventional indirect strategies might be perceived as overpolite from a modern perspective (cf. Locher 2004: 90).

The analysis takes into consideration the different pragmatic functions of these expressions and the level of fixation reached by some of them. For this purpose, it will make use of the Corpus of Late Eighteenth-Century Prose, compiled by David Denison and Linda van Bergen, which comprises a collection of letters (c. 300,000 words) sent to Richard Orford, a steward of Peter Legh the Younger at Lyme Hall in Cheshire, in the period 1761-1790. The corpus includes dialectal English of the North-West, which was relatively uninfluenced by prescriptivist ideas. The letters included usually deal with everyday subject-matter, often combining business and personal affairs (see van Bergen and Denison 2007).

\section{Performatives and request strategies in English}

Austin's (1975: 6) broadly defined "performative" verbs as those verbs that 'perform' different actions (Austin 1975: 6). Such actions may be realized through a performative verb, that is, "the verb naming the action while performing it" (Huang 2007: 95). Thus, when an action is realized by uttering the verb, the action is an "explicit performative", whereas "implicit performatives" do 
not contain a performative verb (Austin 1975: 32). Fraser (1996: 173) includes performative expressions (e.g. I promise, I request, we invite you) within his catalogue of pragmatic markers, since they can convey the speaker's communicative intention beyond theit literal meaning. Thus, performatives are regarded one of the source categories of pragmatic/discourse markers (cf. Landone 2009: 89; Ghezzi 2014: 26), due to their pragmatic function.

Blum-Kulka (1987) and Blum-Kulka et al. (1989) offer a catalogue of the different request strategies in Present-day English from more direct to more indirect ones, as shown in Table 1 below. According to this classification, performatives are placed in the most direct side of the continuum:

Table 1. Requests strategies in English (adapted from Blum-Kulka (1987) and Blum-Kulka et al. (1989: 18))

\begin{tabular}{|l|l|l|}
\hline \multirow{4}{*}{ Direct } & Mood derivable & Move your car. \\
\cline { 2 - 3 } & Performatives & I'm asking you to move your car. \\
\cline { 2 - 3 } & Hedged performatives & I would like to ask you to move your car. \\
\cline { 2 - 3 } & Obligation statements & You'll have to move your car. \\
\cline { 2 - 3 } $\begin{array}{l}\text { Conventionally } \\
\text { indirect }\end{array}$ & Want statements & I want you to move your car. \\
\hline \multirow{2}{*}{$\begin{array}{l}\text { Non-conventionally } \\
\text { indirect }\end{array}$} & Suggestory formulae & How about cleaning up? \\
\cline { 2 - 3 } & Query preparatory & Would you mind moving your car? \\
\cline { 2 - 3 } & Mild hints & You've left the kitchen in a right mess. \\
\hline
\end{tabular}

Whereas conventionally indirect requests are the most common strategy in Present-day English, this was not the case in earlier periods of English. Thus, in Late Modern English there were several verbs with meanings related to 'request' in this speech act, and most of them were used performatively. Examples of explicit performatives from early Modern English onwards include $I$ beg, $I$ beseech or I entreat (cf. Akimoto 2000: 78; Sönmez 2005: 11), and their core lexical meaning was similar: 'to ask earnestly'. Pray, which was the most frequent politeness marker in requests in this period, had a performative origin (I pray you), while please, which was starting to emerge in the late eighteenth century, was not an explicit performative since it developed from an imperative followed by an infinitive with to. According to Akimoto (2000: 77-78), the grammaticalization of pray followed a similar path to that of epistemic parentheticals, such as 
I think (cf. Thompson and Mulac 1991), namely the deletion of that in the subordinate clause could enable the free position of the expression as a parenthetical.

Several studies pay attention to requests strategies in the history of English. Sönmez (2005) analyses request expressions in family letters in the seventeenth century, using the Corpus of Early English Correspondence Sampler and other collections. She selects both unmarked requests and conventional indirect requests formulated most commonly with verbs such as beseech, beg, please, entreat, pray and desire. In the period covered by her study, five decades from 1623 to 1660, direct strategies constitute the most frequent way of formulating a request. She also shows that the set of request verbs and strategies used by seniors addressing their juniors is less varied than those used by juniors to address seniors and those used between equals. Thus, Sönmez finds out a correlation between certain expressions and social relations, since generational deference is a determining factor in the choice of requests expressing a higher or lower degree of deference.

Culpeper and Archer's (2008) analysis of requests in trial proceedings and play-texts shows that direct strategies, such as impositives were the most common way to express a request in the seventeenth and eighteenth centuries and reveals that in the period they examine there was no need for mitigation or modification. Culpeper and Archer identify a number of strategies that fit in Blum-Kulka et al.'s (1989) three main groups of request strategies (according to their directness scale): direct, conventionally indirect and hints. While impositives are the most frequent strategy in their study, conventional indirect requests were used mainly by powerful people or intimates of high status. According to Culpeper and Archer, it seems "likely that the lack of distance associated with impositives, particularly imperatives, has neutral or even positive value" (2008: 76). Thus, they find that more power relative to others correlates with greater directness.

Del Lungo Camiciotti (2008) focuses on nineteenth-century commercial letters, and identifies performatives as the most common request strategies, while indirect strategies, the preferred ones in Present-day English, were not so frequent yet. This author relates the use of straightforward strategies to the non-institutional context of business relations, in which participants negotiate both commercial activities and acquaintance. 


\section{Data analysis}

\subsection{Performative verbs in eighteenth-century requests}

Entries corresponding to different performative verbs in eighteenth-century dictionaries reveal several coincidences with regard to the verbs included in their definitions. Thus, in an entry for the verb beg, several other requestive verbs are included: "to pray, beseech, intreat, desire, petition, or crave alms, favour, or assistance of any kind from another" (Dyche 1740, s.v. beg). Similarly, we can identify other synonyms in entries for beseech "to beg, or intreat" (Martin 1749, s.v. beseech) or bid "to desire, to ask; to command, to order; to offer, to propose; to pronounce, to declare; to denounce" (Sheridan 1780, s.v. bid). Verbs such as entreat/intreat, defined as "to beg earnestly, or beseech; to court with fair Words" (Defoe 1735, s.v. entreat) and request "To ask; to solicite; to entreat" (Johnson 1755-56, s.v. request, v.) were among the most frequent terms in eighteenth-century grammars, often used as hypernyms.

Consequently, the performative verbs included in the study are pray, which was the most frequent request marker in the eighteenth century, and the set of verbs identified in eighteenth-century dictionaries and grammars, analysed in the following order from the least to the most common: beseech, entreat/intreat, bid, ask, request, desire, and beg. More attention will be payed to the latter since it showed a wider range of functions in the Corpus of Late Eighteenth-Century Prose. Other verbs found in eighteenth-century grammars or in Sönmez's study, such as beseech, are absent from the corpus. All the searches have been done using WordSmith 6 tools, and all the possible spelling variants of each verb have been considered.

\subsection{Pray}

The verb pray was introduced into English from Anglo-Norman in the thirteenth century, while the courtesy marker pray originated in the verb "from a parenthetical expression, and ultimately from a main clause performative expression" (Traugott and Dasher 2002: 252). Pray as a courtesy marker replaced the native form biddan (Traugott 2000: 1), one of the verbs with the lowest frequencies among those included in the present study (see Section 3.4 below).

Most of the different performative phrases with verbal pray, like I pray you, I pray thee, pray you, pray thee, prithee and I pray were "used to add urgency, solicitation, or deference to a question or request" (OED, s.v. pray v. P1 b). Parenthetical forms of this verb, such as I pray you became fixed and 
started a grammaticalization process as early as the fifteenth century (cf. Akimoto 2000). Hence, pray is completely grammaticalized in the Corpus of Late Eighteenth-Century Prose, which reveals no occurrences of pray with pronouns in subject or object function in requests. Besides, there are no instances of verbal pray in this corpus, other than the formulaic parenthetical expression I pray God (cf. Table 2 below), and examples of pray in its religious sense, or inflected forms (i.e. prays or prayed) are absent from this epistolary collection.

Table 2. Classification of pray in the Corpus of Eighteenth-Century Prose

\begin{tabular}{|l|c|}
\hline FORMS & FIGURES \\
\hline Pray (courtesy marker) & $100 / 33.66^{1}$ \\
\hline Pray (attention getter) & $37 / 12.45$ \\
\hline I pray God & $2 / 0.67$ \\
\hline
\end{tabular}

Regarding its pragmatic functions in this corpus, pray can be found conveying two main usages, either instances of the courtesy marker preceding an imperative, as in (1), which includes a request for an answer, or as an attention getter preceding a question, generally a request for information, as in (2):

1. Pray indulge me with a Line (1789, Edward Barker) ${ }^{2}$

2. Now give me Leave to ask, pray did Mr. Dickenson in any one Jnstance offer to interfere? (1783, John Dickenson)

A previous study (Faya Cerqueiro 2007) purposely excluded from the tally several instances of pray, which were classified as cases where pray might have been wrongly used instead of pay as in (3) below:

3. pray my Complimts to Henry Richardson when you see him \& tell him we shall send him a \%bill of $\mathrm{W}^{\mathrm{m}}$ Turners Expences (1771, W Burchal) ${ }^{3}$

1. Raw numbers and frequencies per 100,000 words in the corpus.

2. Italics are used in all the examples in order to highlight performative expressions.

3. For the conventions and symbols used in the Corpus of Late Eighteenth-Century Prose see van Bergen and Denison (2007). 
Those instances included expressions such as pray my compliments, pray my respects and pray my duty, as shown in Table 3, which are also possible in the same pattern with pay. According to the OED, to pay one's respects is "to show polite attention or deference (to a person) by presenting oneself or by making a call” (s.v. respect n. P7).

Table 3. Fixed expressions with the verb pray

\begin{tabular}{|l|c|}
\hline FORMS & FIGURES \\
\hline pray my compliments & $26 / 8.75$ \\
\hline pray my respects & $3 / 1.01$ \\
\hline pray my duty & $1 / 0.34$ \\
\hline
\end{tabular}

However, a closer look at fixed structures identified with other performative verbs in requests, as found in beg (cf. Table 4), would suggest that those expressions were actually conventionalized with requestive verbs in the eighteenth century.

\subsection{Entreat/Intreat}

Entreat is also a word of French origin, introduced in Middle English (OED, s.v. entreat, v.). Although entreat/intreat was a common word for request (both as a noun and as a verb) in eighteenth-century reference works, as shown in many of the definitions included in 3.1, there is only one instance (0.34) in a non-finite clause:

4. J am perswaded that no one wishes Better to the Public than you do, for which reason let me entreat you never to consent that we shoud next Year keep the Bars in our own hands (?1789, John Dickenson).

The mismatch between the high frequency of entreat/intreat in eighteenth-century grammars and dictionaries and its scarcity in the Corpus of Late Eighteenth-Century Prose could be related to the prescriptivism of most reference books in the period. It is also possible that it just fell in disuse or that the level of formality of this verb was too high for the personal and immediate issues dealt with in this epistolary collection, with many exchanges among family members and business transactions among equals. 


\subsection{Bid}

The native verb biddan was used performatively as a directive in earlier periods in the history of English (Traugott 2000). It is cognate with German bitten, which is still used in Present-day German as a performative verb in requests. German also keeps the pragmatic marker bitte, the equivalent of English please, as the default marker in requests. Most instances of bid in the corpus are found in reported speech, meaning 'To ask pressingly, beg, entreat, pray' (OED, s.v. bid v1) although there is only one instance as a performative, shown in (5):

5. please to Give my Service to all my fellow Servants in Generall I now bid them all a farwell; (1779, Mary Moseley)

The performative verb bid is used here as part of the fixed expression bid farewell, still found in Present-day English, and it could be part of other fixed expressions in the speech act of greetings and farewells (cf. OED, s.v. bid v1, 9). This example is interesting since it also includes the imperative form please to, a pattern which was very frequent in this corpus, and which finally led to the courtesy marker please. The use of this Germanic form was probably already marginal in performative sentences.

\subsection{Ask}

The native verb ask was not very frequent as a requestive verb in the data under analysis, and in fact, most examples of this verb are used with the general meaning 'to question, inquire'. Thus, the corpus yields only nine (3.03) performative uses of the verb meaning 'to make request for a thing desired' (OED, s.v. ask v.), including performatives, as in (6), hedged performatives, as in (7), and want statements, as in (8):

6. Dear sir I ask pardon for not sending the Bills yesterday but was so busy I had not [^"'t" crossed out?^] Opportunity (1771, Daniel Samuel)

7. If I sh ${ }^{\mathrm{d}}$. not be thought troublesome I wou'd ask, for a line from you (1777, Robert Caunce)

8. I want to ask you a bit of advice (1789, James Grimshaw)

The general meaning of this verb makes it also suitable to express different speech acts, as in (6), where it is used as part of an apology. 


\subsection{Request}

The verb request is formed from the homonymous noun, introduced earlier through French, in the fifteenth century (OED, s.v request v1). It became the hypernym and came to name the speech act of requests. The corpus contains 49 (16.49) instances of the verb request, including both performatives, as in (9), and hedged performatives, as in (10):

9. \& I request you to Give my best respects to Mr. Legh (1789, James Leigh)

10. Enclosed you’ve $2 \%$ Bills val: $£ 200$ - must request you will not omit to put us in Cash for the Bill advanced in due Season (1778, W Bowden)

The modal must is the most common way of hedging in the examples analysed, it also occurs with desire and particularly with beg (cf. examples (14), (17), (24) and (27) below). By adding must the writer expresses the obligatory character of the request, as if external circumstances compel him or her to ask the reader to do something.

This verb can also be found with the same meaning and in the same speech act in non-finite clauses depending on other verbs, as in (11), where permit functions as a mitigator of the directive:

11. Permit me, Sir, to request you will not engage yourself until you are fully acquainted with every Circumstance that hath occasioned this intended Separation. (1785, John Boldero)

\subsection{Desire}

The verb desire is also a French loanword and its frequency is considerably high in the corpus (72.03). There are 214 instances including performatives, both with and without an implicit subject, as in (12) and (13) respectively, and hedged performatives, as in (14):

12. I desire the sum may be sent in Bank Notes (17??, Elizabeth Keck)

13. Desire you'l send my Books by the return as I cannot settle with our men till they come to hand. (1774 , Harry Richardson)

14. I must desire you will remit me the Money I lent you, as soon as you can, for I shall really want it. (1779, Martha Legh) 
In spite of its high frequency, this verb was not common in fixed expressions in letters save for some examples, as in (15):

15. I desire your answer by the return of the post, (1781, John Jackson (of Golborne)

Nevertheless, among the instances of desire there are no want statements due to the lexical meaning of the verb, which already carries a volitional connotation.

\subsection{Beg}

According to the $O E D$, beg is etymologically obscure, although there are some suggestions of French origin (s.v. beg, v.). This verb is the most frequent one among the verbs under analysis (74.05), with 220 instances. Most instances include performative uses, as in (16), and hedged performatives, as in (17), while want statements are not very frequent, only two instances (0.67), as in (18):

16. $\mathrm{J}$ am in a very Bad State of Health and $J$ beg you yould Releace mee as soone as posable you can at this time (1771, William Burchall)

17. J must beg Leave to ask you this serious Question, which is all J want to know from You, Was two Guineas a Year, in your Opinion, a full \& adequate Consideration for all the great \& important Advantages J was to give Mr. Jacson? (1780, John Dickenson)

18. I Want to beg a little of your good advice, (1778, E Hancock)

There are three subjectless instances, where beg could be regarded as an imperative followed by a to-infinive construction, as in (19). Although this pattern is not identified with the other performatives under analysis, it is similar to the structure with verbal please (cf. examples (5) above and (22) below):

19. Beg now mr Grimsw, to send my Goose to London when convenient to him. (1783, John Amson)

One of the main differences of beg as compared to the other performative verbs is the range of fixed and conventionalized expressions such as beg pardon, beg excuse, beg leave, which, according to the OED, are "often merely a 
courteous or apologetic mode of asking what is expected, or even of taking as a matter of course". Some of these instances of beg are elliptical "for beg leave" (OED s.v. beg, v.). Table 4 below shows the six more common expressions, which are related not only to the speech act of requests but also to those of greetings or excuses.

Table 4. Fixed expressions with the verb beg.

\begin{tabular}{|l|c|}
\hline FORMS & FIGURES \\
\hline beg the/a favour & $31 / 10.43$ \\
\hline beg my compliments & $17 / 5.72$ \\
\hline beg pardon & $16 / 5.38$ \\
\hline beg leave & $14 / 4.71$ \\
\hline beg my respects & $12 / 4.04$ \\
\hline beg acceptance & $6 / 2.02$ \\
\hline
\end{tabular}

As regards the syntactic patterns of this verb, in addition to the frequent construction $I$ beg + object, identified in the set of fixed expressions in Table 4, the most common patterns in the Corpus of Eighteenth-Century Prose are thatclauses and to-infinitives, as shown in Table 5:

Table 5. Syntactic patterns of the verb beg

\begin{tabular}{|l|c|}
\hline FORMS & FIGURES \\
\hline that-clause (omission of that) & $69 / 23.22$ \\
\hline to-infinitive & $27 / 9.09$ \\
\hline Final position (parenthetical) & $4 / 1.35$ \\
\hline that-clause & $3 / 1.01$ \\
\hline
\end{tabular}

Some instances followed by a to-infintive, as in (20), are regarded by the $O E D$ as "ellipt. in epistolary formulas of goodwill: to desire to send, to offer":

20. As this Alteration is like to take Place soon, there is a young Man in the Garden, I would beg to sollicit $\mathrm{M}=\{*\}=$ Legh's consideration of, that he may be continued a while in the Employ. (1787, Henry Hewitt) 
After fixed transitive constructions, that-clauses with omission of that are the most frequent syntactic pattern, as in (21) below:

21. I shall desire my Witness $\{$ ' $\}$ s to attend \& beg youll bring with you ny Papers (1773, Lowndes Thomas)

Examples such as (21) have been a source for the emergence of some pragmatic markers, such as I think (cf. Thompson and Mulac 1991), since that-clauses with omission of that are a necessary step before fixed expressions move to other positions in the sentence. This would probably be the case of I beg in (22), where it is a parenthetical in final position:

22. Please to send me a ansr. to the Inclosd by first as We shall not go before Wensday fail not I Beg (790, Thomas Gaskell)

In spite of the four occurrences of parenthetical I beg in the data, the degree of grammaticalization reached by beg is questionable. There were several other fixed expressions available in requests in this period, especially pray and please to, which were frequent strategies, the former fully grammaticalized and the latter under grammaticalization at the same time. In addition, none of the four parentheticals with $I$ beg is subjectless, although the omission of first-person subjects is very common due to the nature of the corpus, which very often includes very short answers, even just a few lines long, on business issues. Examples where the subject is omitted are common among performatives, as in (23), used as a parenthesis in a that-clause, and hedged performatives, as in (24):

23. I shoud be very glad if she g coud wait of either of the Ladies at Lyme Old or Young if you think there is any probability, beg you will let me know, the poor thing is very Unhappy at being out of place (1773, W Burchal)

24. Poverty again begins to peep in at Our Windows therefore must beg your assistance for a $100^{£}$ on Tuesday with the Horse if Possible your Compliance (1776, Thomas Gaskell)

With regard to the pragmatic functions of beg, requests, as expected, are the most common speech act where this verb takes place, and performative expressions with beg are particularly common as polite request markers, as in (25). Within the speech act of requests, expressions with beg can be used for specific purposes. Thus, it is very frequent to find a request for an answer, especially in postscripts, as in (26), and also when asking for advice, as in (27): 
25. I beg the favour of you to Send the inclosed to Henry Richason as I propose Coming into Cheshire the end of this month as our famely is gone to Bath (1772, Betty Clayton)

26. I beg $\mathrm{S}^{\mathrm{r}}$ your answer by the return of the Post, as I shou ${ }^{\mathrm{d}}$ be sorry to move anything, you wou ${ }^{d}$ think, wrong (1775, Jane Holford)

27. now I must Beg your kind Addvise how to proseed forder about it. (?1781, E Hancock)

However, the set of functions and speech acts with this verb goes beyond directives. Other speech acts where beg might occur are also related to negative politeness. This is the case of expressives such as excuses and apologies, as in (28) and (29) below. Example (28), an apology at the very beginning of the letter, includes the expression beg your pardon, one of the routinized expressions in Table 4 still common in polite contexts in Present-day English, while (29) also includes the expression I am quite sorry, of more general use nowadays:

28. Dr Sir I most Sincerly beg Your Pardon for not forwarding the Salt Water. as \%Promis'd (1777, John Drinkwater)

29. tell her that I am quite Sorry She as had so much trouble but as it was a case of Nessec $\wedge^{\wedge} \wedge$ ty beg She will excuse it (1779, Mary Moseley)

Other expressive speech acts include salutations and farewells, as in (30) below, placed at the end of the letter:

30. Beg my kind respec ${ }^{\wedge t s} \wedge$ to them if you please, am your trublesume Freind and Humble Sarvint (1785, E Hancock)

The routinized expression beg my respects is one of the common ones identified in Table 4 above. The farewell includes also part of a typical ending formula in personal eighteenth-century letters (your humble servant), and negative politeness is further emphasized by if you please, another common request marker in the period.

\section{Final remarks}

The analysis of the set of performative verbs used in the second half of the eighteenth century has revealed that pray was the only grammaticalized perform- 
ative expression in the Corpus of Eighteenth-Century Prose, although other verbs, namely desire and beg were more common than pray in the study. The case of beg is particularly interesting regarding its syntactic and pragmatic features. Despite the lack of data supporting a full process of grammaticalization in the corpus, this verb shows a high degree of conventionalization, as evidenced in the range of fixed expressions and functions used in the epistolary genre, and its parenthetical use in sentence-final position.

Some verbs included in eighteenth-century grammars and dictionaries are very rare or not attested in the corpus. This fact might point at the prescriptivist character of reference works in this period, which might not be reflected in private letters. The set of performatives available in the speech act of requests in this period includes mainly loanwords from French, while the only native verbs are bid, already very infrequent at the time, and ask, with a very broad meaning and which does necessarily imply a high degree of politeness. This fact suggests the need of new forms to reinforce the negative politeness weight of the request. In addition, the avoidance of routinized expressions in favour of new forms and the use of a wider catalogue of forms can have an effect on the expressiveness and sincerity of the request, especially when using expressions of French origin, since they might incorporate additional courtesy connotations.

Performatives (and also hedged performatives and want-statements) are meant to be direct request strategies, however most of the performative expressions analysed are used in negative politeness contexts. This evidence would corroborate prior studies that identify direct strategies as the most common ones in earlier periods. Moreover, as shown in the selection of examples making use of direct strategies, the lexical meaning of the requestive verb prevails over the syntactic pattern without any face risk for the writer or the reader.

In addition to proper requests, some of the performative verbs analysed, and especially beg, have spread their uses to expressive speech acts such as excusing and apologising, both also typical examples of negative politeness. Most of the expressions used in eighteenth-century letters are still kept in Present-day English with similar values, although many of them are limited to very formal contexts or otherwise perceived as too refined by the modern speaker.

Therefore, this study contributes to the description of the wide catalogue of request markers in the second half of the eighteenth-century, and, in particular, to the set of performative verbs, in a period that witnessed ongoing changes in the selection of politeness markers in the speech act of requests. 


\section{References}

AKIMOTO, M. (2000). "The Grammaticalization of the Verb 'Pray"” in Grammaticalization in English. Pathways of Change. (Eds. O. Fischer, A. Rosenbach and D. Stein). Amsterdam and Philadelphia: John Benjamins: 67-84.

AUSTIN, J. L. 1975 (1962). How to Do Things with Words. Oxford: Clarendon Press.

BLUM-KULKA, S. (1987). "Indirectness and politeness in requests: Same or different?” Journal of Pragmatics 11 (2): 131-146.

BLUM-KULKA, S. et al. (Eds.) (1989). Cross-Cultural Pragmatics: Requests and Apologies. Norwood: N. J. Ablex.

CULPEPER, J. and ARCHER, D. (2008). "Requests and directness in Early Modern English trial proceedings and play-texts, 1640-1760” in Speech Acts in the History of English. (Eds. A. H. Jucker and I. Taavitsainen). Amsterdam and Philadelphia: John Benjamins: 45-84.

CULPEPER, J. and DEMMEN, J. (2011). "Nineteenth-century English politeness: Negative politeness, conventional indirect requests and the rise of the individual self”. Journal of Historical Pragmatics 12 (1/2): 49-81.

DEFOE, B. N. (1735). A new English dictionary. Westminster. Eighteenth Century Collections Online. Gale Group.

DEL LUNGO CAMICIOTTI, G. (2008). "Two polite speech acts from a diachronic perspective: Aspects of the realisation of requesting and undertaking commitments in the nineteenth-century commercial community” in Speech Acts in the History of English. (Eds. A. H. Jucker and I. Taavitsainen). Amsterdam and Philadelphia: John Benjamins: 115-131.

DENISON, D. (Dir.) and VAN BERGEN, L. (Ed.). (2003). Corpus of Late Eighteenth-Century Prose. University of Manchester Faculty of Arts and John Rylands University Library of Manchester.

DYCHE, T. (1740). A New General English Dictionary. 3rd edition. London. Eighteenth Century Collections Online. Gale Group.

FAYA CERQUEIRO, F. (2007). "The courtesy markers pray and please in the late 18th century: Evidence from the Corpus of Late Eighteenth-Century Prose” in Proceedings of the 30th International AEDEAN Conference. (Eds. M. Losada Friend, P. Ron Vaz, S. Hernández Santano and J. Casanova). Huelva: Servicio de Publicaciones de la Universidad de Huelva.

FRASER, B. (1996). "Pragmatic markers". Pragmatics 6: 167-190.

GHEZZI, C. (2014). "The development of discourse and pragmatic markers" in Discourse and Pragmatic Markers from Latin to the Romance Languages. (Eds. C. Ghezzi and P. Molinelli). Oxford: Oxford University Press: 10-26. 
HUANG, Y. (2007). Pragmatics. New York: Oxford University Press.

JOHNSON, S. (1755-56). A Dictionary of the English Language. 2nd edition. London. Eighteenth Century Collections Online. Gale Group.

KLEIN, L. (2002). "Politeness and the interpretation of the British eighteenth century". The Historical Journal 45 (4): 869-898.

LANDONE, E. (2009). Los marcadores del discurso y cortesía verbal en español. Bern, etc.: Peter Lang.

LOCHER, M. (2004). Power and Politeness in Action: Disagreements in Oral Communication. Berlin and New York: Mouton de Gruyter.

MARTIN, B. (1749). Lingua Britannica Reformata: Or, a New English Dictionary. London. Eighteenth Century Collections Online. Gale Group.

OED $=$ Oxford English Dictionary. 3rd edition (in progress) OED Online, March 2000-. (Ed. J. A. Simpson). <www.oed.com>. Oxford: Oxford University Press.

SCOTT, M. (2012). WordSmith Tools version 6. Stroud: Lexical Analysis Software.

SHERIDAN, T. (1780). A General Dictionary of the English Language. London, 2 vols. Eighteenth Century Collections Online. Gale Group.

SÖNMEZ, M. J-M. (2005). "A study of request markers in English family letters from 1623 to 1660”. European Journal of English Studies 9 (1): 9-19.

THOMPSON, S. A. and MULAC, A. (1991). "A quantitative perspective on the grammaticization of epistemic parentheticals in English", in Approaches to grammaticalization, vol. 2. (Eds. E. C. Traugott and B. Heine). Amsterdam and Philadelphia: John Benjamins: 313-329.

TRAUGOTT, E. C. (2000). "Promise and pray-parentheticals". Eleventh International Conference on English Historical Linguistics (ICEHL XI), Santiago de Compostela, September 2000. In Elizabeth C. Traugott. Papers Available On-line. $<$ http://www.stanford.edu/ traugott/ect-papersonline.html $>$.

TRAUGOTT, E. C. and DASHER, R. B. (2002). Regularity in Semantic Change. Cambridge: Cambridge University Press.

VAN BERGEN, L. and DENISON. D. (2007). "A Corpus of Late EighteenthCentury Prose" in Creating and Digitizing Language Corpora, vol. 2, Diachronic Corpora. (Eds. J. C. Beal, K. P. Corrigan and H. Moisl). Basingtroke: Palgrave Macmillan: 228-246.

WŁODARCZYK, M. (2013). "1820 settler petitions in the Cape Colony: Genre dynamics and materiality”. Journal of Historical Pragmatics 14 (1): 45-69. 